\title{
Production of Hydrogen by Steam Methane Reformation Process
}

\author{
T Younus $^{1 *}$, A Anwer $^{2}$, Z Asim², M S Surahio ${ }^{2}$ \\ ${ }^{1}$ Assistant Professor, Szabist, Karachi and 75600, Pakistan \\ ${ }^{2}$ Student, Szabist, Karachi and 75600, Pakistan
}

\begin{abstract}
Upcoming hydrogen economy is on rise on political agenda due to growing need of hydrogen. Natural occurrence of hydrogen cannot satisfy the present need of hydrogen. It produces a wide gap between current hydrogen requirement and amount of hydrogen present in earth. To counter this problem, hydrogen is produced commercially in industries through various methods. Among all these methods, SMR (Steam Methane Reforming) process is considered most feasible for being economically cheap as compared to other methods. Being economical does not necessarily mean being eco-friendly. Industrialist does not switch on alternative methods and continue using SMR process which is producing a devastating impact on atmosphere by increasing the amount of $\mathrm{CO} 2$ (carbon dioxide). Greenhouse effect of carbon dioxide makes it one of the primary sources of increasing global warming in earth's atmosphere. Apart of other uses, Hydrogen can also be used as eco-friendly energy source as compared to fossil fuel used as energy source. In this paper, the procedure of production of hydrogen through SMR process is reviewed in detail and its pros and cons are discussed.
\end{abstract}

\section{Introduction}

Currently electricity, natural gas, solar heat, gasoline and diesel serve as energy source to drive this world $[1,2]$. These energy carriers are converted from primary energy sources such as coal, petroleum, underground methane and nuclear energy. Conversion of primary source to usable source produces harmful by-products which have made necessary for humans to convert to more ecofriendly and clean energy. These energy sources include wind energy, solar energy, tidal energy and hydrogen etc. hydrogen being limited in its natural form need to be produced commercially. Once produced can serve as one of the clean eco-friendly energy source with no carbon emission. Currently hydrogen is mainly used to produce ammonia and methanol. It is also used for hydro treating refineries. Hydrogen is widely used for hydrogenation reactions for unsaturated hydrocarbons, aromatics, aldehydes and ketones and nitrogen compounds. Other uses include use of hydrogen in food industry, semiconductor industry and metallurgical industry. Some more uses include mixture of hydrogen and nitrogen in synthesis of ammonia and mixture of hydrogen and carbon oxide in synthesis of methanol, liquid hydrocarbons and higher alcohols [3]. Taking all these uses of hydrogen in account, some methods for commercial production of hydrogen have been proposed having their own advantages and disadvantages.

\section{Literature Review}

Extensive usage of fossil fuel results in the increased amount of greenhouse gases and other air pollutants, this highlights the need of new methods for the production of energy. Developing hydrogen as an energy carrier may answer to this open challenge [4-6]. Bio-Fermentation is one of the technique to produce hydrogen [7]. Hydrogen can be a sustainable source to meet the- need of energy in the near future is discussed by Turner [8]. Hydrogen is sustainable source of renewable energy $[9,10]$. Geological hydrogen storage methods and its transmission lines for transportation is discussed by Leighty [11]. Hydrogen is found to be one of the main energy carrier for the production of sustainable energy [12 - 17]. Economy may face some positive prospective along with few challenges which is in detailed discussed by Abbasi and Abbaso [18]. Residual gasses production in greenhouse is greatly reduced by using hydrogen as compared to fossil fuels. A new era of clean energy is emerging nowadays, in which hydrogen plays a prominent role [19-25]. The environmental effect of hydrogen production can be assessed through a life cycle of system used presented by Smitkova [26]. Hydrogen is not freely available in atmosphere but can be extracted/produced using several systems. Coal, water, natural gas, and oil are the sources that produce hydrogen in its purest form. Among many processes few are; (a) Steam Methane Reforming (SMR), (b) Coal Gasification, (c) Water Electrolysis, (d) Fermentation of Biomass and (e) Thermochemical Cycles [27-34]. More than $90 \%$ of hydrogen is produced using SMR, Dufour et al. [35] stated that it is one of the main cause of releasing carbon dioxide. However hydrogen can also be produced through separation of water molecules using electrical 
power (electrolyzers). In order to produce 1,000 Joules of energy 1,600 Joules of hydrogen is required [36].

Techniques that can be used to produce hydrogen can be categorized according to the source used for production of hydrogen. Among all these techniques, SMR (steam methane reforming) method is considered to be the most efficient and feasible procedure. [Being economical and producing $99.9 \%$ pure hydrogen, a lot of industrialists are investing on commercial production of hydrogen through Steam Methane Reforming Process]. The steam reforming procedure seems to be a simple procedure as product composition can be expressed by simple thermodynamics but in reality it is a complex procedure which includes a combination of complex mechanical design, catalyst and heat transfer.

In past years, there have been modifications in this process which allowed more efficient and less expensive commercial units due to the changes in material of reformer tubes, better control and understanding of carbon limits and better catalyst and process concept developed over time.

\section{Methodology}

A simple hydrogen plant producing hydrogen by SMR process is explained below. Natural gas is heated beforehand in the waste side of the reformer and zinc oxide catalyst removes sulphur. Treated steam is included, and the combination of natural gas and steam is further heated before going in the tabular reformer. In this step, transformation of equilibrium of hydrogen, carbon monoxide and carbon dioxide occurs in presence of nickel based catalyst. The gas leaves the reformer and is cooled by production of steam before going in the shift converter. In presence of shift catalyst, further production of hydrogen takes place by processing carbon monoxide and steam into carbon dioxide and hydrogen. The converted gas is cooled to room temperature before going into PSA unit. Pure hydrogen gas is produced and the offgas from PSA unit is used in the reformer as fuel supplemented with natural gas [37].

Figure 1 shows the summary of steam methane reformation process. Whole process of SMR (steam methane reforming) process can be summarized in three equations. These are

$$
\mathrm{CH}_{4}+\mathrm{H}_{2} \mathrm{O}=3 \mathrm{H}_{2}+\mathrm{CO}(\Delta \mathrm{H} 298 \mathrm{~K}=206 \mathrm{~kJ} / \mathrm{mol})
$$

$\mathrm{CO}+\mathrm{H}_{2} \mathrm{O}=\mathrm{CO}_{2}+\mathrm{H}_{2}(\Delta \mathrm{H} 298 \mathrm{~K}=-41 \mathrm{~kJ} / \mathrm{mol})[38]$

$\mathrm{CO}_{2}$ is also produced as a by-product when hydrogen is produced [2]. Quantity of $\mathrm{CO}_{2}$ produced mainly depends on the presence of carbon element and technique used for production [1]. Chemical process of carbon produces 1 volume of $\mathrm{CO}_{2}$ per volume of $\mathrm{H}_{2}$. Whereas 0.25 volume of $\mathrm{CO}_{2}$ per volume of $\mathrm{H}_{2}$ is produced by steam reforming of methane and higher efficiency plants produces 0.37 volume of $\mathrm{CO}_{2}$ per volume of $\mathrm{H}_{2}$. It can also be represented as 8.1 tone $\mathrm{CO}_{2}$ per ton $\mathrm{H}_{2}$ [39]. These are pretty high values of carbon emission and when released in atmosphere can produce pretty harmful effects on atmosphere producing greenhouse effects and increasing average temperature of earth. Carbon emission is one of the major reasons for global warming causing climatic change season cycle all around the world. To counter these effects, a technique termed as carbon sequestration is proposed.
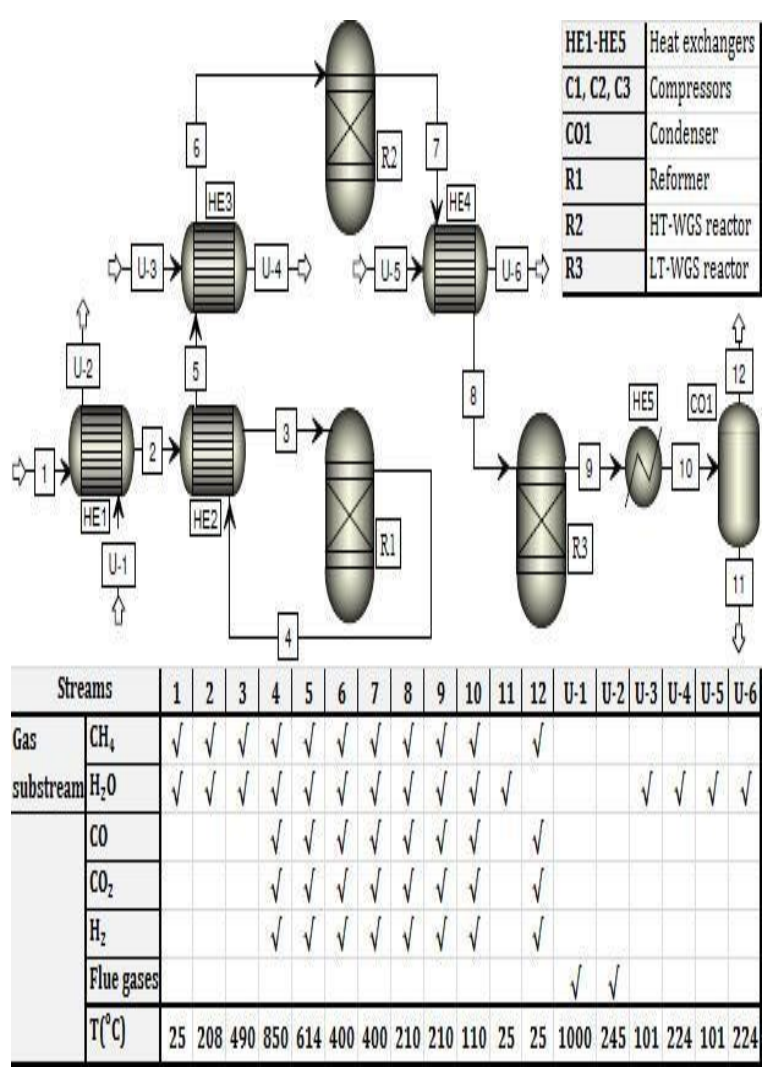

Figure 1. Steam Methane Reformation Process Working Principle [38]

\section{Dumping of Carbon through Carbon sequestration process}

Carbon sequestration is the long-term storage of carbon in oceans, soils, vegetation (especially forests), and geologic formations [4]. It is still under experimentation phase. According to this concept, carbon dioxide will be mainly dumped into deep ground and under deep sea beds. Apparently it appears to be a good idea to get rid of excessive carbon dioxide from atmosphere but it has its own drawbacks that cannot be ignored. Some of its major drawbacks are listed below.

The most substantial risk associated with CCS is the leakage of $\mathrm{CO} 2$ from storage sites. There is little encounter with geological deposition of natural gas and $\mathrm{CO} 2$ for time interval of almost $10-20$ years but a long term deposition of hundreds or thousands of years is not proved[40]. Excessive concentration of carbon dioxide can change the carbon content of soil. It is good for some crops that can grow well in excessive but overall effect can be dangerous. Most of the crops need limited proportion of carbon content and increased carbon concentration can damage crop's growth and change crop cycle as well. 
Another option of storing excessive carbon dioxide is to store in deep sea beds. Excessive carbon can play a major role in growth of planktons and reefs but overall marine could get in danger thus disturbing the marine life cycle and ultimately food chain.

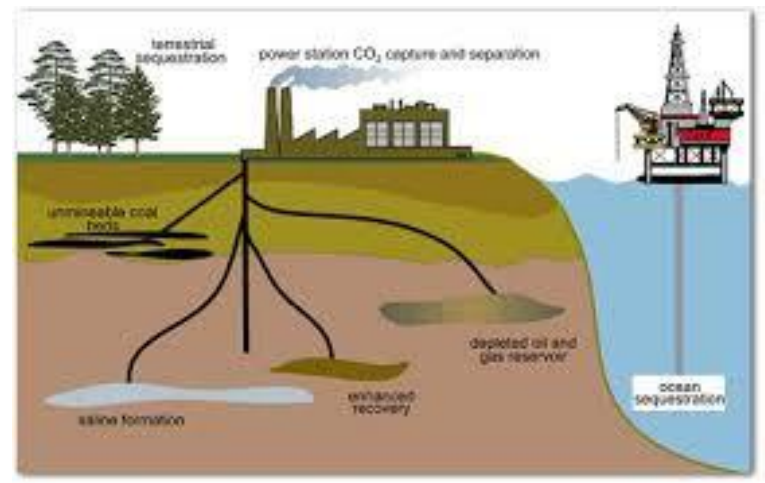

Figure 2. Carbon Sequestration Methods [41]

Fig. 2 shows different methods of carbon sequestration according to the application. Land industries are dumping carbon underground and ocean industries are dumping carbon in ocean beds.

\section{Alternate Method}

Alternate methods for producing carbon emission free hydrogen is following bio- hydrogen route.

Bio -hydrogen is fuel obtained by microbial metabolism, which is bioethanol or biogas. Bio hydrogen can be produced by mainly two mechanisms. These mechanisms include sunlight based microbial photosynthesis using water or organic subtract and dark fermentation by heterotrophic bacteria using sugar, starches etc. difference between these two methods is based on microorganism used. Sunlight based micro- organic photosynthetic uses green microalgae, cyano-bacteria whereas dark fermentation uses fermentative bacteria. However bio-hydrogen produces about $20-25 \%$ of hydrogen [42].

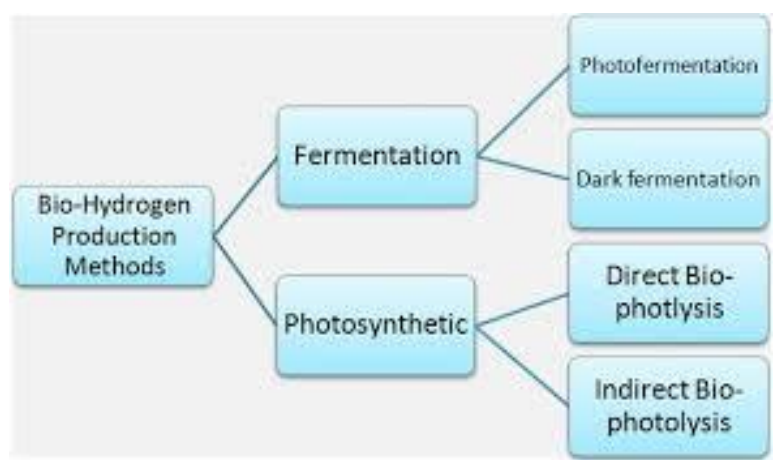

Figure 3. Bio Hydrogen Production Methods [26-33]

Fig. 3 shows the different type of methods of bio hydrogen methods of production.

\section{Result}

Analytically bio hydrogen procedure for producing commercial hydrogen appears to be costly and less efficient as compared to the SMR (steam methane reforming) process. Steam methane reforming process is more efficient as compared to other methods of production of Hydrogen. Huge amount of carbon dioxide emission from steam methane reforming process raises questions on future of hydrogen as alternative energy source.

\section{Discussion}

Production of hydrogen through steam methane process produces about $99.9 \%$ pure hydrogen which can be used as alternative energy source but produces huge amount of carbon dioxide which will affect earth's atmosphere indirectly. On both conditions i.e. producing hydrogen from steam methane process and using it as an alternate energy source or directly obtaining energy by burning fossil fuel have adverse effects on earth's atmosphere and increasing global warming rapidly.

\section{Conclusion}

This paper gives deep insight about production of Hydrogen through Steam Methane Reformation process and why it should not be continued in future. Carbon emission and its effect on atmosphere is one of the major issue which needs to be controlled on right time. Not taking any action on right time can cause a huge setback to the humanity by in forms of natural catastrophes.

\section{References}

1. Koroneos, C, Spachos, T, Moussiopoulos, N, Exergy analysis of renewable energy sources, Renewable Energy, 2003; Volume 28, Issue 2, 295 310

2. Younas, T, Saadat, M, Hussain, I, Rashied, Z, "Design and Fabrication of Power Generator through Busy Roads", Energy Procedia, 2017; 118C, 104-109: 1876-6102

3. Antzaraa, A., Heracleousa, E., B. Bukurc, D., \& A. Lemonidoua, A. (2014). Thermodynamic analysis of hydrogen production via chemical looping steam methane reforming coupled with in situ $\mathrm{CO} 2$ capture. Energy Procedia 63, 6576 - 6589.

4. Gadalla, MA, Ratlamwala, TAH, Dincer, I., Kanoglu, M. Performance assessment of an integrated absorption cooling-hydrogen liquefaction system using geothermal energy. International Journal of Exergy 2013; 12 (2): 205-25.

5. Clark, WW, Rifkin, J, O'Connor, T, Swisher, J, Lipman, T, Rambach, G. Hydrogen energy stations: along the roadside to the hydrogen economy. Utilities Policy 2005; 13 (1): 41-50.

6. Ratlamwala, TAH, Dincer, I. Performance assessment of solar based integrated $\mathrm{Cu}-\mathrm{Cl}$ systems for hydrogen production. Solar Energy 2013; 95: 345-56. 
7. Argun, H, Kargi, F. Bio-hydrogen production by different operational modes of dark and photofermentation: An overview. International Journal of Hydrogen Energy 2011; 36 (13): 7443-59.

8. Turner, JA. Sustainable hydrogen production. Science 2004; 305: 972-4.

9. Dincer, I., Ratlamwala, TAH. Development of Novel Renewable Energy Based Hydrogen Production Systems: A Comparative Study. Energy Conversion and Management 2013; 72: 77-87.

10. Ratlamwala, TAH, Dincer, I and Aydin, M. Energy and exergy analyses and optimization study of an integrated solar heliostat field system for hydrogen production. International Journal of Hydrogen Energy 2012; 37: 18704-12.

11. Leighty, W. Running the world on renewable: Hydrogen transmission pipelines and firming geologic storage. International Journal of Energy Research 2008; 32: 408-26.

12. Dincer, I, Ratlamwala, TAH. Importance of exergy for analysis, improvement, design, and assessment. Wiley Interdisciplinary Reviews: Energy and Environment 2013; 2 (3): 335-49.

13. Bicakova, O, Straka, P. Production of hydrogen from renewable resources and its effectiveness, International Journal of Hydrogen Energy 2012; 37: 11563-78.

14. Moriarty, P, Honnery, D. Hydrogen's role in an uncertain energy future. International Journal of Hydrogen Energy 2009; 34: 31-9.

15. Dincer, I. Environmental and sustainability aspects of hydrogen and fuel cell systems. International Journal of Energy Research 2007; 31: 29-55.

16. Ratlamwala, TAH, Dincer, I, Gadalla, MA and Kanoglu, M. Thermodynamic analysis of a new renewable energy based hybrid system for hydrogen liquefaction. International Journal of Hydrogen Energy 2012; 37 (23): 18108-17.

17. Ratlamwala, TAH, Dincer, I. Development of a geothermal based integrated system for building multigenerational needs. Energy and Buildings 2013; 62: 496-506.

18. Abbasi, T, Abbaso, SA. 'Renewable' hydrogen: Prospects and challenges. Renewable and Sustainable Energy Reviews 2011; 15: 3034-40.

19. Gadalla, MA, Ratlamwala, TAH, Dincer, I. Energy and exergy analyses of an integrated fuel cell and absorption cooling system. International Journal of Exergy 2010; 7(6): 731-54.

20. Muradov, NZ, Veziroglu, TN. "Green" path from fossil-based to hydrogen economy: An overview of carbon-neutral technologies. International Journal of Hydrogen Energy 2008; 33: 6804-39.

21. Midilli, A, Dincer, I. Development of some exergetic parameters for PEM fuel cells for measuring environmental impact and sustainability. International Journal of Hydrogen Energy 2009; 34: 3858-72.

22. Ratlamwala, TAH, Dincer, I, Gadalla, MA. Performance analysis of a novel integrated geothermal-based system for multigeneration applications. Applied Thermal Engineering 2012; 40(1): 71-79.

23. Midilli, A, Dincer, I. Hydrogen as a renewable and sustainable solution in reducing global fossil fuel consumption. International Journal of Hydrogen Energy 2008; 33: 4209-22.

24. Mohammed, MAA, Salmiation, A, Wan-Azlina, WAKG, Amran, M, Fakru'l-Razi, A, Taufiq-Yap, YH. Hydrogen rich gas from oil palm biomass as a potential source of renewable energy in Malaysia. Renewable and Sustainable Energy Reviews 2011; 15: 1258-70.

25. Ratlamwala, TAH, Dincer, I, Gadalla, MA. Thermodynamic analysis of a novel integrated geothermal based power generation-quadruple effect absorption cooling-hydrogen liquefaction system. International Journal of Hydrogen Energy 2012; 37 (7): 5840-49.

26. Smitkova, M, Janicek, F, Riccardi, J. Life cycle analysis of processes for hydrogen production. International Journal of Hydrogen Energy 2011; 36: 7844-51.

27. Abuadala, A, Dincer, I. A review on biomass-based hydrogen production and potential applications. International Journal of Energy Research 2012; 36: 415-55.

28. Ratlamwala, TAH, Dincer, I. Comparative efficiency assessment of novel multi-flash integrated geothermal systems for power and hydrogen production. Applied Thermal Engineering 201; 48: 359-66.

29. Abd-Alla, MH, Morsy, FM, El-Enany, AE. Hydrogen production from rotten dates by sequential three stages fermentation. International Journal of Hydrogen Energy 2011; 36: 13518-27.

30. Joshi, AS, Dincer, I, Reddy, BV. Exergetic assessment of solar hydrogen production methods. International Journal of Hydrogen Energy 2010; 35: 4901-8.

31. Ratlamwala, TAH, Gadalla, MA, Dincer, I. Performance assessment of an integrated PV/T and triple effect cooling system for hydrogen and cooling production. International Journal of Hydrogen Energy 2011; 36(17): 11282-91.

32. Ratlamwala, TAH, El-Sinawi, AH, Gadalla, MA, Aidan, A. Performance analysis of a new designed PEM fuel cell. International Journal of Energy Research 2012; 36 (11): 1121-32.

33. Tsuchiya, H. Innovative renewable energy solutions for hydrogen vehicles. International Journal of Energy Research 2008; 32: 427-35.

34. Ratlamwala, TAH, Gadalla, MA, Dincer, I. Thermodynamic analysis of an Integrated PEMFCTEARS-geothermal system for sustainable buildings. Energy and Buildings 2012; 44(1): 73-80.

35. Dufour, J, Serrano, DP, Galvez, JL, Moreno, J, Garcia, C. Life cycle assessment of processes for hydrogen production: environmental feasibility and reduction of greenhouse gases emissions. International Journal of Hydrogen Energy 2009; 34: 1370-76. 
36. Burman, G. Hydrogen Isn't Yet the Miracle Fuel of the Future. The Fresno Bee 2003.

37. Hallenbeck, P., \& Benemann, J. (n.d.). Biohydrogen - The Microbiological Production of Hydrogen Fuel. In P. C. Hallenbeck, \& J. R. Benemann, Biotechnology - Vol.VII.

38. New York State Energy Research and Development Aut. (n.d.). Amiqweb.es. Retrieved fromamiqweb.es: www.amiqweb.es/app/download/.../6hydrogenpr oductionsteammethanereforming.pdf

39. Nielsen, J., \& -Nielsen, T. (2002). Large-scale Hydrogen Production. T. Cattech, 6(4), 150-159.
40. Shahbazi, A., \& Nasab, B. (2016). Carbon Capture and Storage (CCS) and its Impacts on Climate Change and Global Warming. Journal of Petroleum \& Environmental Biotechnology.

41. Paper online: https://www.quora.com/How-iscarbon-sequestration-useful-to-the-environment

42. Udengaard, N. (2004). Hydrogen Production by Steam Reforming Of Hydrocarbons. Prepr. Pap.-Am. Chem. Soc., Div. Fuel Chem., 49(2), 906. 